\title{
Pemanfaatan Limbah Kulit Pisang Menjadi Nata de Musa di Kabupaten Lumajang
}

\author{
Bekti Palupi, Felix Arie Setiawan, Istiqomah Rahmawati, Nadhilah Shabrina, I Made \\ Arimbawa \\ Teknik Kimia, Fakultas Teknik, Universitas Jember \\ bekti.palupi@unej.ac.id
}

\begin{abstract}
Abstrak
Kabupaten Lumajang merupakan salah satu daerah yang berada di kawasan tapal kuda Provinsi Jawa Timur dengan sentra industri pengolahan pisang Karunia Jaya di Desa Kalipenggung, Kecamatan Randuagung. Usaha pengolahan pisang yang secara langsung mendorong pertumbuhan ekonomi di Kabupaten Lumajang, baik dari sektor pemasukan maupun tenaga kerja sehingga keberlangsungannya sangat penting demi kemajuan daerah Lumajang sebagai sentra industri pertanian. Kulit pisang dapat dimanfaatkan menjadi produk unggulan seperti Nata de Musa, tepung kulit pisang, bioplastik, dll. melalui serangkaian proses produksi. Melimpahnya kulit pisang dari sisa produksi pengolahan pisang dapat dimanfaatkan menjadi produk olahan karena kulit pisang memiliki komposisi air 68,90\%, karbohidrat 18,50\%, lemak $2,11 \%$, protein $0,32 \%$ dan komposisi kandungan kimia lainnya. Tingginya kandungan karbohidrat dari kulit pisang membuat bahan ini sangat cocok untuk digunakan sebagai bahan dasar nata de musa. Oleh karena itu, pembuatan nata dari kulit pisang sangat cocok sebagai diversifikasi produk olahan kulit pisang. Kegiatan dibagi menjadi dua tahapan yakni sosialisasi terkait pemanfaatan kulit pisang menjadi nata dan praktik langsung pembuatan nata dari kulit pisang. Kegiatan ini menghasilkanwawasan tambahan bagi masyarakat bahwa limbah kulit pisang tidak hanya dibuang atau dijadikan pakan ternak dimana limbah kulit pisang dapat dimanfaatkan menjadi Nata de Musa sehingga memiliki nilai tambah.Produk Nata de Musa dapat dijadikan sebagai produk unggulan Desa Kalipenggung dan meningkatkan perekonomian warga.
\end{abstract}

Kata kunci: kulit pisang, nata de musa, Lumajang

\begin{abstract}
Lumajang Regency is one of the areas located in the horseshoe area of East Java Province with the Karunia Jaya banana processing industrial center in Kalipenggung Village, Randuagung District. Banana Business which directly encourages economic growth in Lumajang Regency, both from the income and labor sectors, must support its sustainability for the sake of the development of the Lumajang area as a center for the agricultural industry. Banana peel can actually be utilized as a superior product such as Nata de Musa, banana skin flour, bioplastics, etc. through the completion of the production process. This is possible because of the composition contained in a banana peel, namely $68.90 \%$ air, $18.50 \%$ fat, $2.11 \%$ fat, $0.32 \%$ protein and other chemical compositions. The high nutritional content of banana peels makes this material very suitable for use as a nutrient in the growth of the microbial Acetobacter xylinum. Therefore, making nata from banana peels is very suitable as a diversification of processed banana peel products. The activity was divided into two stages of socialization related to the use of banana peels into nata and the practice of making nata directly from banana peels. This activity generates additional insights for the community that banana peel waste is not only used or used as animal feed while banana peel waste can be used as Nata de Musa. Nata de Musa products can be made as a superior product of Kalipenggung Village and improve the welfare of residents.
\end{abstract}

Keywords: Banana peels, Nata de Musa, Lumajang 


\section{PENDAHULUAN}

\section{A. Analisis Situasi}

Kabupaten Lumajang merupakan salah satu daerah yang berada di kawasan tapal kuda Provinsi Jawa Timur. Secara geografis, Lumajang berada pada posisi $112^{\circ} 53^{\prime}$ - $113^{\circ} 23$ Bujur Timur dan $7^{\circ} 54^{\prime}-8^{\circ} 23$ Lintang Selatan'. Kabupaten Lumajang beriklim tropis. Berdasarkan klasifikasi curah hujan Schmidt dan Ferguson sebagian wilayah termasuk tipe $C$ yang bersifat agak basah dan sebagian lainnya bertipe D yang bersifat sedang. Bulan-bulan kering dengan jumlah curah hujan kurang dari $100 \mathrm{~mm}$ perbulan, terjadi pada bulan-bulan Juli, Agustus dan September, sementara bulan-bulan lainnya adalah bulan basah. Jumlah curah hujan tahunan berkisar antara 1.500-2.500 mm. Temperatur sebagian besar wilayah berada pada kisaran $24^{\circ} \mathrm{C}-32^{\circ} \mathrm{C}$. Kabupaten Lumajang memiliki potensi diantaranya sektor pertanian dengan komoditas andalan padi dan produk buah-buahan segar seperti pisang raja dan pisang mas kirana.

Sektor pertanian adalah sektor yang menggerakkan perekonomian masyarakat Indonesia. Selain merupakan sumber pemenuh kebutuhan hidup sebagian masyarakat Indonesia, produksi pertanian juga meningkatkan citra Indonesia di dunia Internasional. Data dari Badan Pusat Statistik (BPS) menyatakan bahwa pada triwulan II 2017, hasil pertanian selalu memberikan sumbangan untuk perekonomian nasional. Data BPS menunjukkan produk domestik bruto Indonesia mencapai 3.366,8 triliun.

Mayoritas produk pertanian hanya dijual sebagai bahan mentah tanpa adanya pengolahan menjadi produk lanjutan yang mempunyai nilai jual lebih tinggi sehingga pendapatan masyarakat khususnya petani sangat minim. Menurut Data dari BPS, angka kemiskinan di Kabupaten Lumajang untuk tahun 2015 dan 2016 berturut-turut adalah $11,52 \%$ dan 11,22\%. Kendati terjadi penurunan angka kemiskinan di Kabupaten Lumajang, peran pemerintah dan akademisi untuk terus meningkatkan perekonomian masyarakat sangat diperlukan demi kesejahteraan masyarakat yang lebih baik. Hal ini sejalan dengan salah satu Rencana Induk Penelitian (RIP) Universitas Jember 20162020 tentang teknologi maju dan berkelanjutan pengelolaan sumber daya alam di wilayah tapal kuda.

Pisang dan produk olahan pisang menjadi suatu ikon dari Kabupaten Lumajang, yang seringkali disebut sebagai "kota pisang". Hal ini tidak terlepas dari jumlah produksi pisang di kabupaten ini seperti terlihat pada Gambar 1.l. Potensi buah pisang ini membuat usaha pengolahan pisang menjadi tumbuh berkembang di daerah Lumajang. Usaha pengolahan pisang yang secara langsung mendorong pertumbuhan ekonomi di Kabupaten Lumajang, baik dari sektor pemasukan maupun tenaga kerja sehingga keberlangsungannya sangat penting demi kemajuan daerah Lumajang sebagai sentra industri pertanian. Walaupun begitu, usaha pengolahan pisang menghasilkan limbah berupa kulit pisang yang hanya digunakan sebagai pakan ternak atau dibuang sebagai sampah. Menurut Lukankubo (2007) jumlah dari kulit pisang cukup banyak, yaitu kira-kira 1/3 dari buah pisang yang belum dikupas. ${ }^{1}$ Potensi kulit pisang yang

Lukankubo. 2007. "Manfaat kulit Pisang”. http://lokanbuko.multiply.com/journal/item/40. Diakses tanggal 25 April 2019. 
dapat diproses menjadi Nata de Musa dapat dikalkulasikan dari Gambar 1, sekitar 395.000 kuintal pertahun.

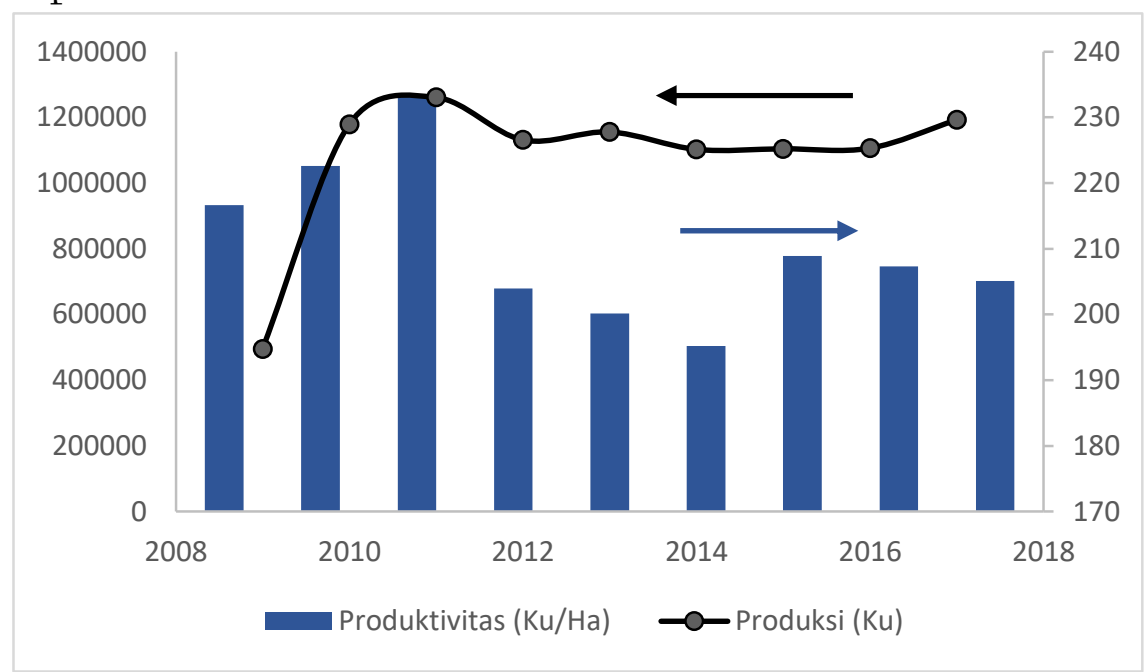

Gambar 1. Produksi Pisang di Kabupaten Lumajang Jawa Timur

Limbah kulit pisang yang terdapat di sentra industri pengolahan pisang Karunia Jaya Lumajang dapat dilihat pada Gambar 2.Kulit pisang sendiri sejatinya dapat dimanfaatkan menjadi produk unggulan seperti Nata de Musa, tepung kulit pisang, bioplastik, dll melalui serangkaian proses produksi. Nata de Musa adalah hidangan yang terlihat seperti jeli, berwarna putih hingga bening dan bertekstur kenyal menyerupai Nata de Coco yang berasal dari kulit pisang. Hal ini mungkin untuk dilakukan karena komposisi yang terkandung dalam kulit pisang, yaitu air 68,90\%, karbohidrat 18,50\%, lemak 2,11\%, protein 0,32\% dan komposisi kandungan kimia lainnya. ${ }^{2}$ Menurut Ariani (2010), kandungan kulit pisang berupa karbohidrat 18,5\%, fosfor $28 \mathrm{mg}$, air $72 \mathrm{~g}$ dan beberapa zat kimia lainnya. ${ }^{3}$ Selain itu, berdasarakan penelitian yang telah dilakukan oleh Someya dkk. (2002) membuktikan bahwa pada kulit pisang memiliki aktivitas antioksidan yang lebih tinggi dibandingkan dengan daging buahnya. Senyawa antioksidan yang terdapat pada kulit pisang yaitu katekin, gallokatekin dan epikatekin yang merupakan golongan senyawa flavonoid. ${ }^{4}$ Selain itu, kandungan unsur gizi yang terdapat pada kulit pisang cukup lengkap, seperti karbohidrat, lemak, protein, kalsium, fosfor, zat besi, vitamin B, vitamin C dan air sehingga kulit pisang memiliki potensi yang cukup baik untuk dimanfaatkan sebagai sumber antioksidan pada bahan pangan..$^{5}$ Beragamnya kandungan gizi dari kulit pisang yang dapat dijadikan berbagai produk olahan makanan ini menjadi peluang tersendiri bagi masyarakat untuk meningkatkan kemandirian ekonomi.

Munadjim. 1983. Teknologi Pengolahan Pisang. Gramedia. Jakarta.

Ariani. 2010. "Pemanfaatan Kulit Pisang dalam Pembuatan Cuka”. http://aksiguru.org. Diakses tanggal 25 April 2019.

4 Someya, S., Yoshiki, Y., dan Okubo, K. 2002. Antioxidant Compounds from Bananas (Musa cavendish). Food Chemistry. 79 (3): 351-354.

5 Zuhrina. 20ll. Pengaruh Penambahan Tepung Kuilt Pisang(Musa paradisiciaca) Terhadap Daya Terima Kue Donat. Skripsi. Universitas Sumatera Utara. 


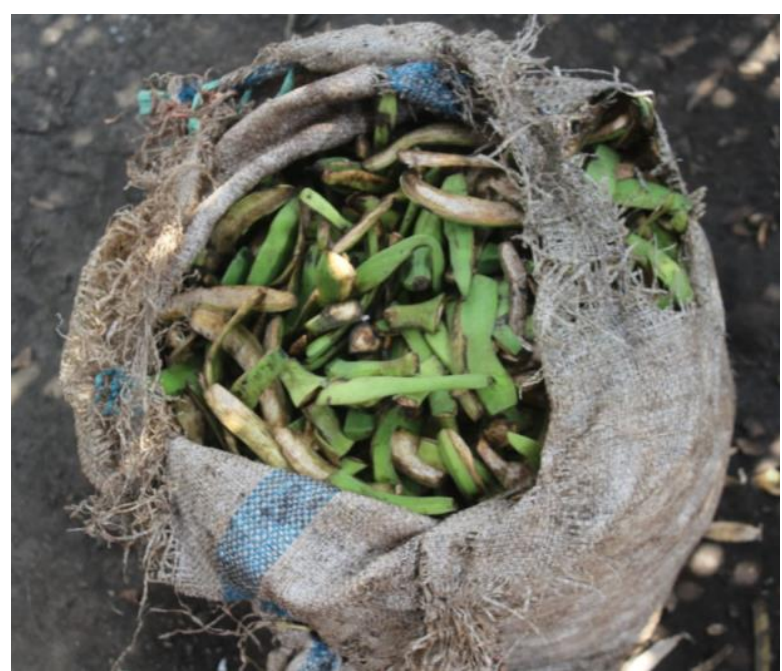

Gambar 2. Limbah Kulit Pisang

\section{B. Permasalahan Mitra}

\section{Identifikasi permasalahan yang dihadapi}

Berdasarkan analisis situasi dan kondisi lingkungan diatas, ada beberapa persoalan terkait diversifikasi produk olahan pisangpada Tabel 1 berikut.

Tabel 1.Persoalan di Kabupaten Lumajang

\begin{tabular}{|l|l|l|}
\hline No. & \multicolumn{1}{|c|}{ TINJAUAN } & \multicolumn{1}{c|}{ PERSOALAN } \\
\hline $\mathbf{1}$ & $\begin{array}{l}\text { Diversifikasi produk } \\
\text { olahan pisang }\end{array}$ & $\begin{array}{l}\text { Masyarakat hanya fokus pada pengolahan } \\
\text { diversifikasi produk olahan buah pisang seperti } \\
\text { kripik (varian rasa), nugget pisang, dan sale tanpa } \\
\text { melihat potensi bahan lain yang dapat } \\
\text { dimanfaatkan, dalam hal ini adalah kulit pisang. }\end{array}$ \\
\hline $\mathbf{2}$ & $\begin{array}{l}\text { Pengolahan kulit } \\
\text { pisang }\end{array}$ & $\begin{array}{l}\text { Minimnya pengetahuan masyarakat mengenai } \\
\text { proses pengolahan kulit pisang sebagai produk } \\
\text { unggulan menjadi kendala yang utama. Pemahaman } \\
\text { masyarakat mengenai nilai kulit pisang yang } \\
\text { dianggap remeh memperberat kondisi yang ada } \\
\text { sehingga perlu dilakukan sosialisasi yang masif } \\
\text { beserta dengan pelatihan untuk menanggulangi } \\
\text { masalah ini. }\end{array}$ \\
\hline $\mathbf{3}$ & $\begin{array}{l}\text { Proses standardisasi } \\
\text { dan sertifikasi }\end{array}$ & $\begin{array}{l}\text { Proses pengolahan kulit pisang menjadi Nata de } \\
\text { Musa membutuhkan beberapa bahan yang dianggap } \\
\text { kaum awam sebagai bahan yang tidak lazim } \\
\text { digunakan seperti Urea dan ZA. Urea dan ZA } \\
\text { merupakan senyawa yang kaya akan nitrogen yang } \\
\text { berfungsi sebagai sumber makanan bakteri. Bahan- } \\
\text { bahan tersebut aman dipergunakan dalam industri } \\
\text { makanan pada batasan jumlsh tertentu. Adanya } \\
\text { proses pencucian dengan menggunakan air pada }\end{array}$ \\
\hline
\end{tabular}




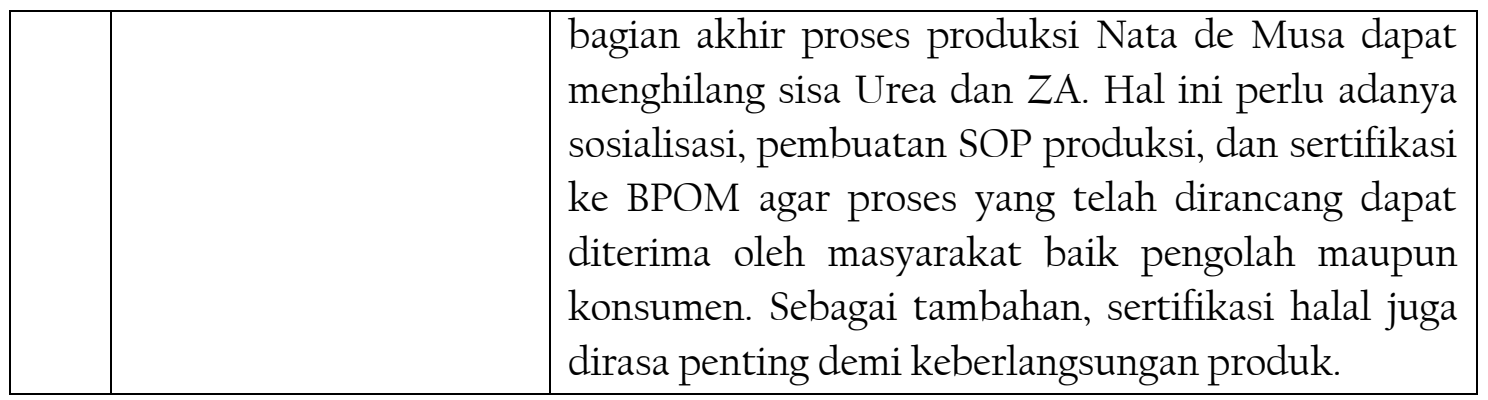

Dari analisa situasi diatas, maka akan muncul persoalan terkait evaluasi pengelolaan dan pengolahan kulit pisang menjadi Nata de Musa, diantaranya:

a. Penumpukan jumlah kulit pisang yang hanya menjadi pakan ternak atau dibuang dapat diolah menjadi produk olahan makanan berupa Nata de Musa. Lebih lanjut, sisa dari pengolahan Nata de Musa masih dapat dimanfaatkan menjadi pakan ternak.

b. Kurangnya pengetahuan pelaku usaha dalam Standar Operasi Pengolahan bahan makanan yang baik sehingga kualitas yang dihasilkan tidak sama antara produksi yang satu dengan yang lain.

c. Kurangnya pengetahuan masyarakat mengenai pentingnya sertifikasi dari BPOM maupun dari MUI untuk memperluas pasar dan menjamin kualitas dari produk yang dihasilkan.

\section{Justifikasi prioritas penyelesaian permasalahan yang ditangani}

Sesuai urutan identifikasi masalah di atas, maka justifikasi prioritas permasalahan adalah:

a. Masyarakat hanya fokus pada diversifikasi pengolahan pisang, tetapi tidak memperhatikan potensi kulit pisang dan hanya membuangnya atau menjadikannya sebagai pakan ternak.

b. Pengetahuan masyarakat masih minim dalam hal pengolahan kulit pisang.

c. Masyarakat belum memiliki pengetahuan yang cukup tentang standardisasi dan sertifikat halal untuk produk olahan dari kulit pisang.

\section{SOLUSI DAN METODE}

\section{A. Solusi yang Ditawarkan}

Pada analisis situasi yang telah dikemukakan, potensi pemanfaatan kulit pisang yang belum optimal sebagai bahan baku pangan mendorong pengusulan diversifikasi produk dengan menerapkan ilmu pengetahuan untuk meningkatkan ekonomi masyarakat Kabupaten Lumajang. Tingginya kandungan karbohidrat dari kulit pisang membuat bahan ini sangat cocok untuk digunakan sebagai bahan baku pembuatan Nata de Musa. Oleh karena itu, pembuatan nata dari kulit pisang sangat cocok sebagai diversifikasi produk olahan kulit pisang. Nata sendiri merupakan olahan makanan 
produk hasil fermentasi menggunakan mikroba Acetobacter xylinum. ${ }^{6}$ Acetobacter xylinum dapat tumbuh dan berkembang membentuk nata dalam media yang mengandung air, protein, lemak dan karbohidrat. Pengolahan kulit pisang menjadi Nata de Musa dapat menjadi diversifikasi produk makanan di Kabupaten Lumajang. Kulit pisang yang selama ini dianggap remeh ingin ditingkatkan nilainya menjadi produk olahan makanan yang dapat langsung dijual dan meningkatkan citra Kabupaten Lumajang sebagai "kota pisang". Pengolahan kulit pisang ini juga diharapkan dapat mengurangi dampak pencemaran yang ditimbulkan dari sentra industri pengolahan pisang berupa keripik dan sale. Hal ini mendorong akademisi Universitas Jember untuk melakukan pengabdian kepada masyarakat bekerja sama dengan sentra industri pengolahan pisang demi berlangsungnya kesinambungan penerapan ilmu untuk berdaya guna bagi masyarakat sekitar.

\section{B. Metode Pelaksanaan}

Kegiatan pengabdian masyarakat dilaksanakan pada September-November 2019 disentra pengolah pisang Karunia Jaya di Desa Kalipenggung.

1. Perencanaan sosialisasi dan pembekalan manajemen pengelolaan dan pengolahan kulit pisang Materi sosialisasi dan pembekalan serta tujuan dari pemberian materi dijelaskan pada Tabel 2 berikut.

Tabel 2. Materi Sosialisasi dan Pembekalan Kegiatan Pengabdian Masyarakat

\begin{tabular}{|c|c|c|c|}
\hline No. & $\begin{array}{l}\text { Jenis Materi } \\
\text { Pembekalan }\end{array}$ & $\begin{array}{c}\text { Tujuan Pemberian } \\
\text { Materi }\end{array}$ & Peserta Pembekalan \\
\hline 1 & $\begin{array}{l}\text { Sosialisasi tentang } \\
\text { pengolahan dan } \\
\text { pengelolaan kulit pisang } \\
\text { menjadi Nata de Musa }\end{array}$ & $\begin{array}{l}\text { Untuk memastikan } \\
\text { masyarakat mampu } \\
\text { melakukan } \\
\text { pengolahan dan } \\
\text { pengelolaan agar } \\
\text { sesuai standar } \\
\text { produksi yang layak }\end{array}$ & $\begin{array}{lr}\begin{array}{l}\text { Sentra } \\
\text { pengolahan }\end{array} \\
\text { Karunia pisang } \\
\text { Kalipenggung, } \\
\text { Randuagung, } \\
\text { Kabupaten Lumajang } \\
\text { serta masyarakat } \\
\text { sekitar }\end{array}$ \\
\hline
\end{tabular}

Kegiatan pengabdian kepada masyarakat berupa sosialisasi dan pembekalan terhadap masyarakat sekitar diharapkan dapat terlaksana dan berjalan dengan baik.

\section{Praktik pengolahan kulit pisang menjadi nata de musa}

Proses pengolahan kulit pisang dimulai dari pengumpulan limbah kulit pisang hasil proses produksi pengolahan pisang menjadi keripik dan atau sale. Semua kulit pisang dapat digunakan karena kandungan kimia yang hampir sama untuk kulit pisang. Tahapan pengolahan kulit pisang menjadi Nata de Musa adalah sebagai berikut:

\footnotetext{
${ }^{6}$ Suryani, A., Erliza, H., dan Prayoga, S. 2005. Membuat Aneka Nata. Penebar Swadaya. Jakarta.
} 
a. Cuci dan potong-potong kulit pisang, kemudian haluskan dengan blender dengan komposisi 2:1. Kemudian saringlah dengan menggunakan saringan kain.

b. Didihkan ekstrak kulit pisang dalam panci, kemudian tambahkan gula pasir sebanyak 75 gr per liter.

c. Ukurlah pH dari ekstrak kulit pisang. Apabila pH-nya diatas 4-4,5 tambahkan asam cuka atau asam asetat glasial sampai pH menjadi 4 - 4,5. Kemudian saringlah dengan menggunakan saringan.

d. Masukkan ekstrak kulit pisang ke dalam nampan atau baskom plastik atau wadah lainnya, kemudian tutup dengan kertas yang bersih, beri keterangan dan simpan di tempat yang aman.

e. Setelah suhunya mencapai $30^{\circ}-40^{\circ} \mathrm{C}$, masukkan cairan bibit sebanyak $165 \mathrm{ml} /$ liter dan Nutrisi berupa ZA dan atau Urea dengan perbandingan tertentu.

f. Setelah 10-15 hari akan terbentuk lapisan putih pada permukaan ekstrak kulit pisang. Angkatlah lapisan tersebut. Hati-hati jangan sampai lapisan bawahnya terkontaminasi, karena cairan ini dapat digunakan sebagai bibit dalam proses produksi selanjutnya.

g. Rendam lapisan putih (nata) tadi selama 2 - 3 hari untuk menghilangkan asamnya. Setiap hari, air rendaman harus diganti dengan air yang baru.

h. Buang lapisan/selaput tipis yang melekat pada bagian bawah lapisan putih tadi, kemudian potong-potong lapisan putih yang diperoleh sesuai dengan bentuk yang diinginkan, lalu dicuci hingga bersih.

i. Kemudian ditiriskan. Didihkan nata sampai bau asamnya hilang (dapat ditambah perisa) lalu potong-potong dan kemas.

\section{HASIL DAN PEMBAHASAN}

Program pengabdian kepada masyarakat berupa Pemanfaatan Limbah Kulit Pisang menjadi Nata de Musa di Kabupaten Lumajang telah dilaksanakan dengan baik, terstruktur, dan melibatkan masyarakat langsung. Kegiatan ini dilaksanakan pada Kelompok Tani Karunia Jaya di Desa Kalipenggung, Lumajang sejumlah 20 orang. Detail hasil dan pembahasan kegiatan pengabdian masyarakat dapat diuraikan sebagai berikut.

\section{A. Sosialisasi Pengelolaan Kulit Pisang dan Cara Pengemasannya}

Kegiatan sosialisasi tentang pengelolaan kulit pisang dan cara pengemasannya dilakukan pada Tanggal 20 Oktober 2019 di Balai Desa Kalipenggung, Lumajang. Kegiatan ini diikuti oleh karyawan dan karyawati industri keripik pisang Karunia Jaya. Acara sosialisasi ini bertujuan untuk membuka wawasan masyarakat, khususnya karyawan dan karyawati Karunia Jaya bahwa kulit pisang bisa dimanfaatkan dan memiliki nilai lebih jika dibuat menjadi nata. Pembuatan Nata de Musa tidak memerlukan biaya yang besar, sehinga dapat dijangkau oleh semua lapisan masyarakat. Selain disampaikan tentang potensi kulit pisang yang bisa diolah menjadi nata, pada 
acara ini juga disampaikan cara pengemasan produk Nata de Musa dan beberapa syarat yang dibutuhkan agar produk tersebut dapat dijual ke pasaran.

Kegiatan ini berisi penyampaian materi terkait pengelolaan dan pengolahan kulit pisang serta cara pengemasannya. Masyarakat sangat antusias ketika acara berlangsung. Hal ini ditandai dengan adanya beberapa pertanyaan dari peserta. Proses penyampaian materi dan sesi tanya jawab dapat dilihat pada Gambar 3 dan Gambar 4.

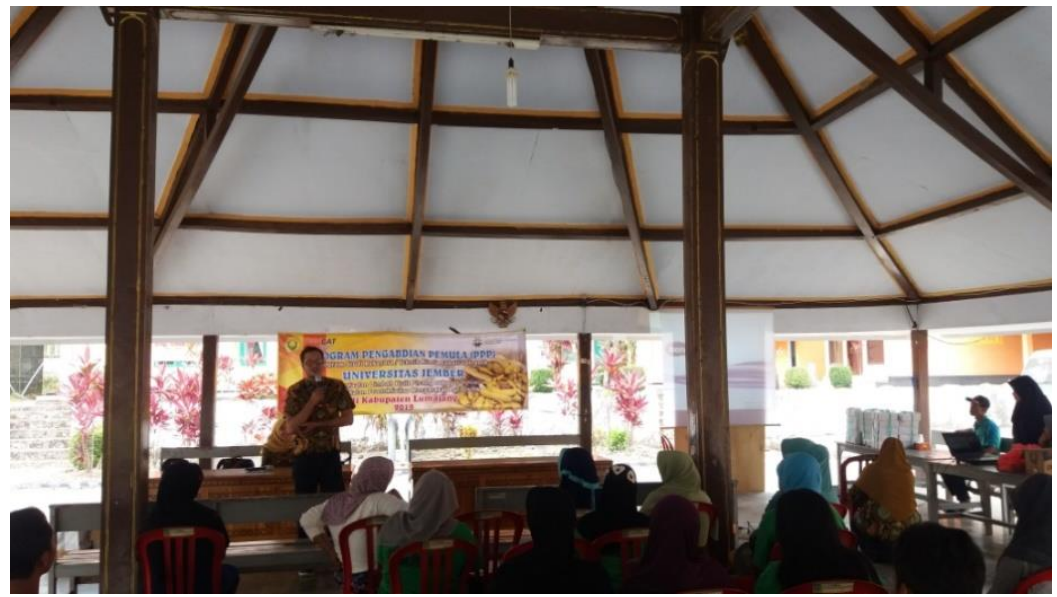

Gambar 3. Penyampaian Materi Sosialisasi

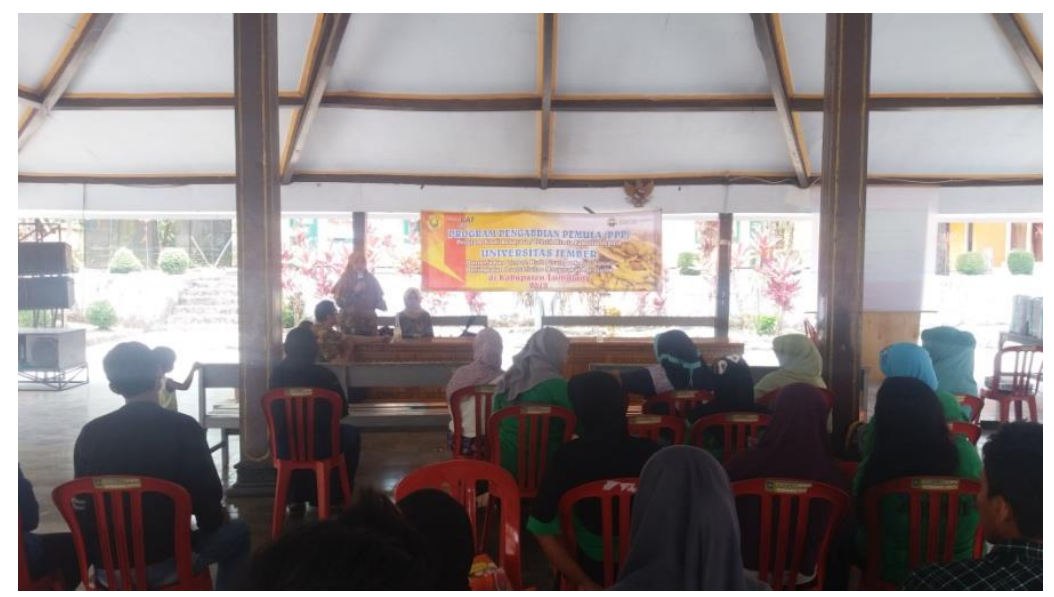

Gambar 4. Sesi Tanya Jawab

\section{B. Kegiatan Pengolahan Kulit Pisang Menjadi Nata de Musa}

Kegiatan praktik pengolahan kulit pisang menjadi Nata de Musa dilaksanakan pada Tanggal 27 Oktober 2019. Acara ini bertempat di Balai Desa Kalipenggung dan diikuti oleh karyawan dan karyawati Karunia Jaya. Proses pembuatan Nata de Musa dipraktikkan secara langsung oleh tim pengabdian diikuti oleh masyarakat sasaran. Kulit pisang diiris kecil-kecil dan diblender dengan komposisi 2 kulit pisang ditambahkan dengan $2 \mathrm{~L}$ air. Setelah dihancurkan dengan blender, sari dari kulit pisang tersebut dipisahkan dari padatannya menggunakan kain serbet. Sari tersebut dididihkan dan ditambah dengan cuka $4 \%$, asam sitrat $2 \%$, gula pasir $20 \%$, dan fermipan 0,4\%. Proses pemasakan sari kulit pisang dapat dilihat pada Gambar 5. 


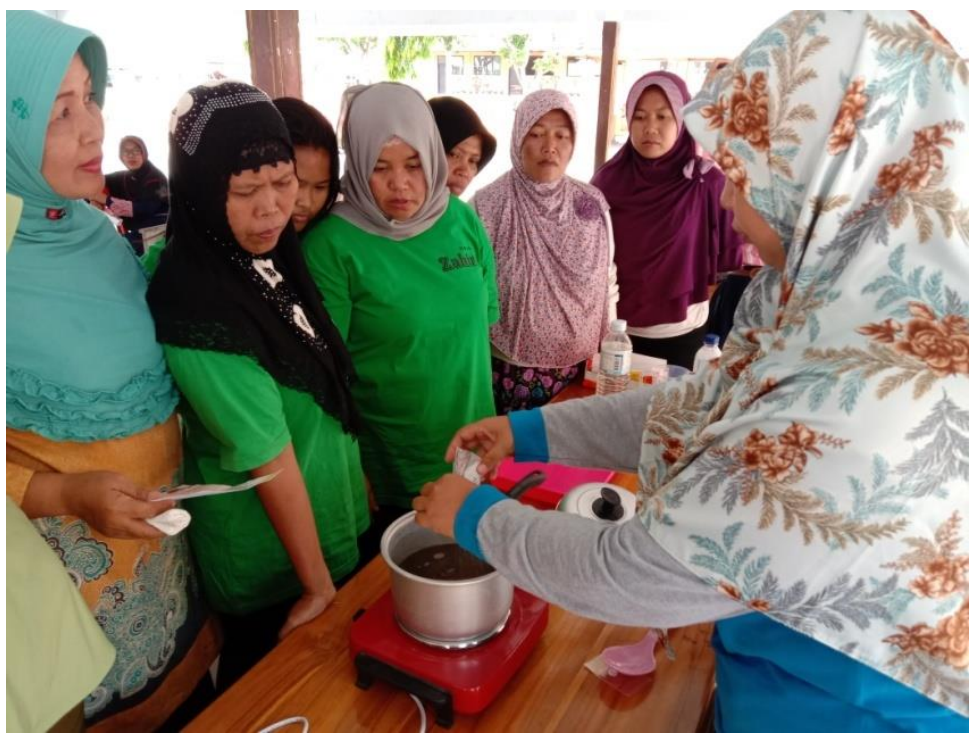

Gambar 5. Proses Perebusan Sari Kulit Pisang

Setelah proses perebusan, sari kulit pisang didiamkan agar dingin dan dituangkan ke dalam nampan yang sudah disterilisasi menggunakan alkohol 70\% seperti pada Gambar 6. Agar tidak terkontaminasi dan tetap steril, nampan ditutup dengan kertas koran seperti pada Gambar 7.

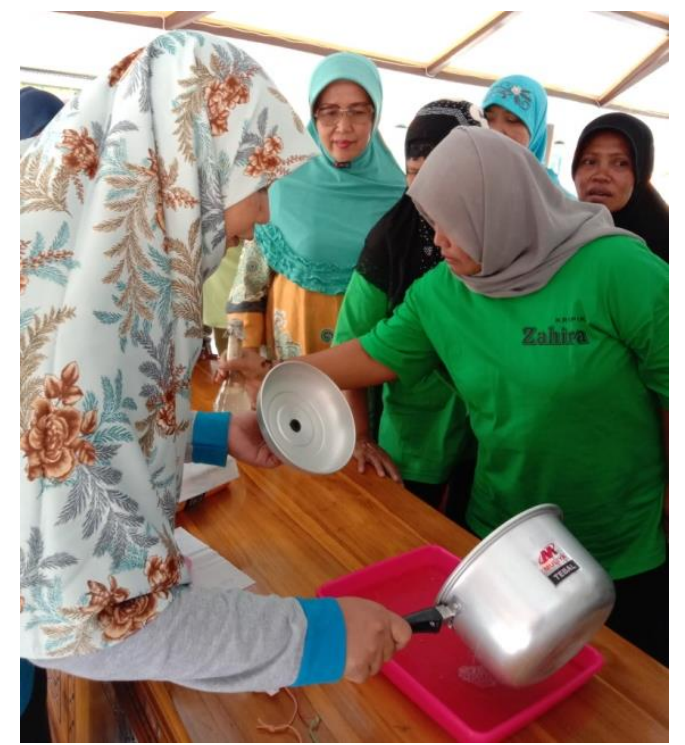

Gambar 6. Penuangan Sari Kulit Pisang ke Nampan

Pemilihan penutup dengan menggunakan kertas koran dikarenakan mudah didapat dan juga berpori sehingga Acetobacter xylinum tetap tersuplai oksigen tanpa terkontaminasi udara dari luar. Kertas koran yang digunakan sebagai penutup juga harus disetrika terlebih dahulu agar steril. Starter nata ditambahkan setelah sari kulit pisang benar-benar dingin agar Acetobacter xylinum tidak mati. Setelah 14 hari yaitu pada Tanggal 10 November 2019, nata dapat dipanen. Nata yang sudah dipanen kemudian 
dicuci dan direbus. Nata siap disajikan dan siap dikemas sebagai produk unggulan Desa Kalipenggung.

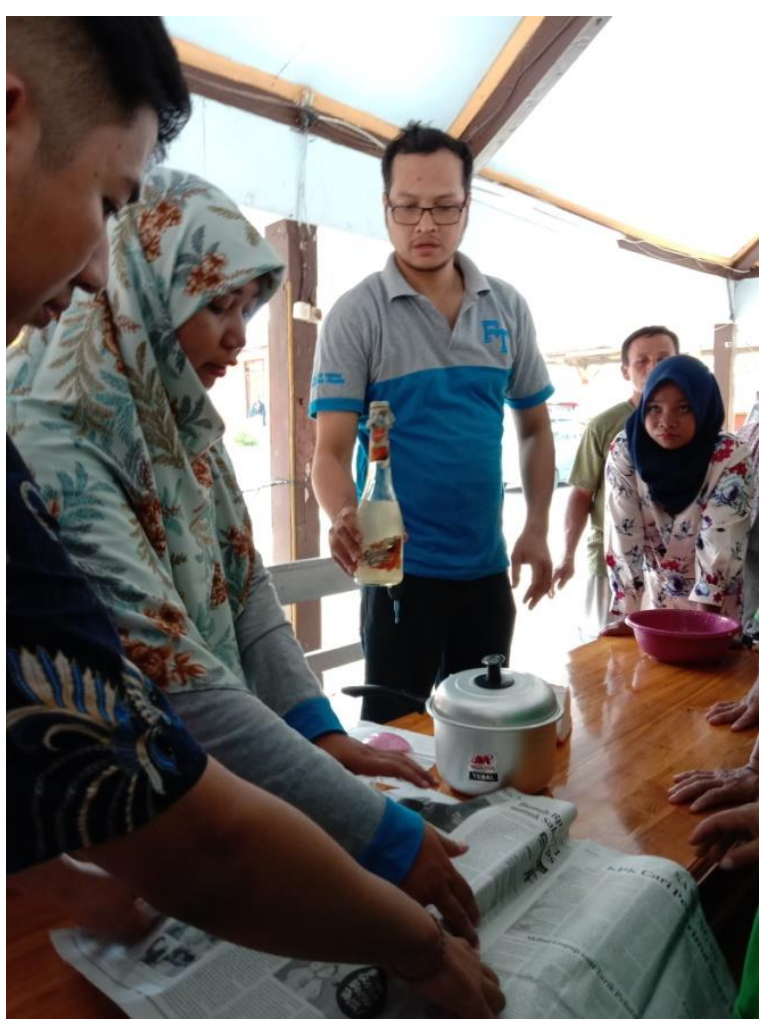

Gambar 7. Penutupan Nampan dengan Kertas Koran

\section{Hasil Pembuatan Nata de Musa}

Hasil pembuatan sari kulit pisang yang sudah difermentasi selama 14 hari dapat dilihat pada Gambar 8. Proses selanjutnya adalah mencuci Nata de Musa sampai bersih. Kemudian nata diiris sesuai dengan selera atau dipotong dalam bentuk dadu. Hasil irisan nata direbus hingga mendidih dan bisa ditambahkan air gula untuk proses kemasan. Nata de Musa yang sudah dikemas dan siap saji dapat dilihat pada Gambar 9.

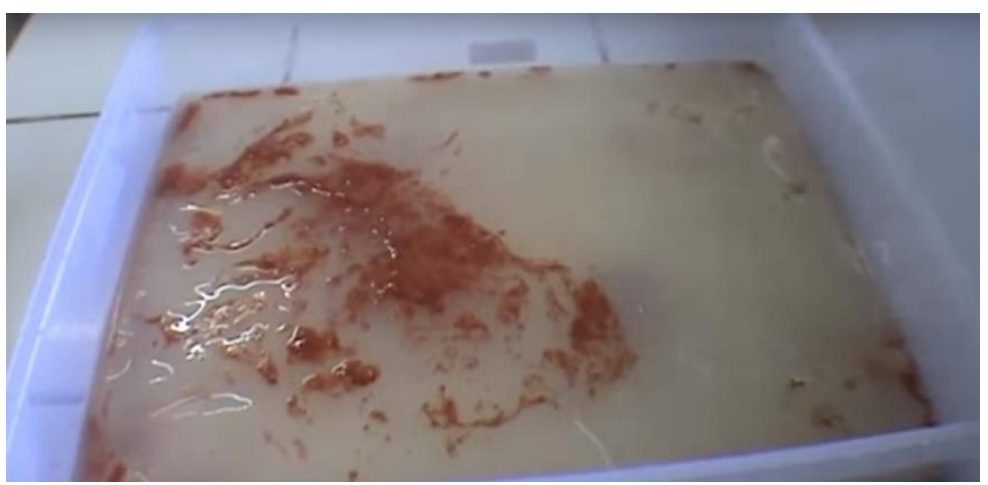

Gambar 8. Nata de Musa dari Kulit Pisang 


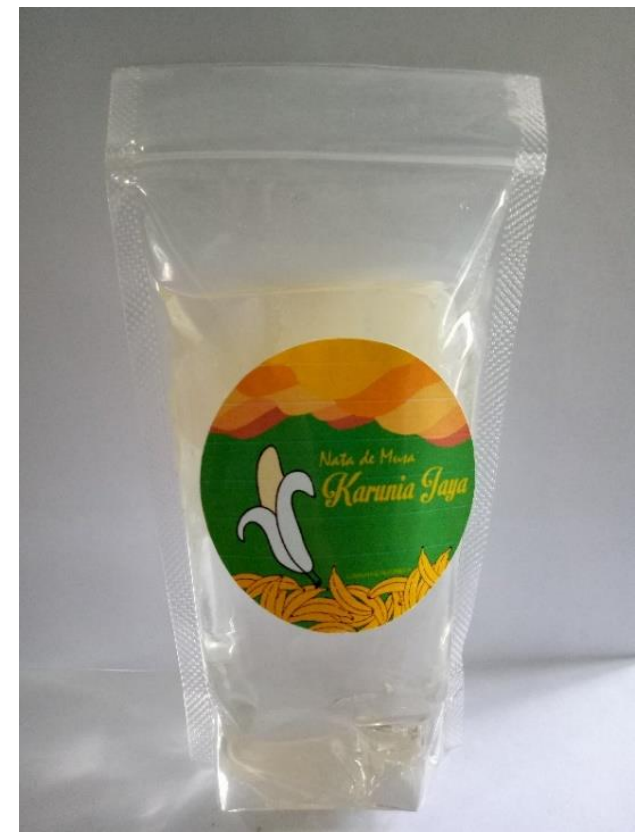

Gambar 9. Kemasan Nata de Musa

\section{KESIMPULAN}

Program pengabdian masyarakat Fakultas Teknik Universitas Jember dengan mitra sentra industri pengolahan pisang Karunia Jaya di Desa Kalipenggungyang berupa kegiatan sosialisasi dan pelatihan pembuatan Nata de Musa dalam upaya peningkatan produktivitas masyarakat agribisnis di Kabupaten Lumajang dapat diterima dengan baik. Pihak mitra mendapat wawasan tambahan bahwa limbah kulit pisang tidak hanya dibuang atau dijadikan pakan ternak tapi dapat dimanfaatkan menjadi Nata de Musa sehingga memiliki nilai tambah. Produk Nata de Musa dapat dijadikan sebagai produk unggulan Desa Kalipenggung yang memiliki keunggulan kandungan nutrisi tinggi dan biaya produksi murah sehingga dapat meningkatkan perekonomian warga.

\section{DAFTAR PUSTAKA}

Ariani. 2010. "Pemanfaatan Kulit Pisang dalam Pembuatan Cuka”. http://aksiguru.org. Diakses tanggal 25 April 2019.

Lukankubo. 2007. "Manfaat kulit Pisang". http://lokanbuko.multiply.com/journal/item/40. Diakses tanggal 25 April 2019.

Munadjim. 1983. Teknologi Pengolahan Pisang. Gramedia. Jakarta.

Someya, S., Yoshiki, Y., dan Okubo, K. 2002. Antioxidant Compounds from Bananas (Musa cavendish). Food Chemistry. 79 (3): 351-354.

Suryani, A., Erliza, H., dan Prayoga, S. 2005. Membuat Aneka Nata. Penebar Swadaya. Jakarta.

Zuhrina. 2011. Pengaruh Penambahan Tepung Kuilt Pisang(Musa paradisiciaca) Terhadap Daya Terima Kue Donat. Skripsi. Universitas Sumatera Utara. 